IRA-International Journal of Education \&

Multidisciplinary Studies

ISSN 2455-2526; Vol.17, Issue 01 (Q1, 2021)

Pg. no. 18-26.

IRA Academico Research

\title{
Exploration and Practice of the Integration of Curriculum Ideology and Politics with Middle School English Teaching
}

\author{
Wang Juan ${ }^{1 \#}$, Ji Chunping ${ }^{2}$, Zhou Haiyun ${ }^{3}$, Zeng Yuxin ${ }^{4}$, Zhao Yinglian $^{5}$
}

1.2,3.4.5 School of Foreign Language, Yangtze University, Jingzhou, Hubei, China.

\# corresponding author

Type of Work: Peer Reviewed.

DOI: 10.21013/jems.v17.n1.p3

DOI URL: https://dx.doi.org/10.21013/jems.v17.n1.p3

How to cite this paper:
Juan, W. et al. (2021). Exploration and Practice of the Integration of Curriculum Ideology and Politics
with Middle School English Teaching. IRA-International Journal of Education \& Multidisciplinary Studies
(ISSN 2455-2526), 17(1), 18-26. DOI: https://dx.doi.org/10.21013/jems.v17.n1.p3

(C) IRA Academico Research.

(c) $\mathbf{B}$ BY-No This work is licensed under a Creative Commons Attribution-NonCommercial 4.0 International License subject to a proper citation to the publication source of the work.

Disclaimer: The scholarly papers as reviewed and published by IRA Academico Research are the views and opinions of their respective authors and are not the views or opinions of IRA Academico Research. IRA Academico Research disclaims of any harm or loss caused due to the published content to any party.

IRA Academico Research is an institutional publisher member of Publishers International Linking Association Inc. (PILA-CrossRef), USA. IRA Academico Research is an institutional signatory to the Budapest Open Access Initiative. Hungary advocating the open-access of scientific and scholarly knowledge. IRA Academico Research is a registered content provider under Open Access Initiative Protocol for Metadata Harvesting (OAl-PMH).

The journal is indexed \& included in WorldCat Discovery Service (USA), CrossRef Metadata Search (USA), WorldCat (USA), OCLC (USA), Open J-Gate (India), EZB (Germany) Scilit (Switzerland), Airiti (China), Bielefeld Academic Search Engine (BASE) of Bielefeld University, Germany, PKP Index of Simon Fraser University, Canada. 


\begin{abstract}
There is no platform and mechanism for the integrated construction of curriculum content. This is reflected in the layout of the syllabus, curriculum standards, teaching objectives, and teaching content of universities, middle schools, and primary schools, and the overall arrangement has not yet been formed. Secondly, the content of ideological and political courses is duplicated. Third, there are gaps in the content of ideological and political courses. Finally, the content of ideological and political courses is inverted. Although the content of the ideological and political course as a whole embodies the line of understanding from low to high, from concrete to abstract, the phenomenon of abstract in primary schools and normative and concrete in universities still exists to varying degrees.
\end{abstract}

Keywords: curriculum ideology and politics; ideological and political education; Middle School English teaching.

\title{
I. Research Background
}

The 17th issue of "Seeking Truth" published on September 1, 2020, published an important article by Xi Jinping, General Secretary of the CPC Central Committee, President of the State, and Chairman of the Central Military Commission, "Ideological and Political Course is a Key Course for the Implementation of the Fundamental Task of Lide and Fostering People." General Secretary Xi Jinping pointed out that it is necessary to coordinate the promotion of the integrated construction of ideological and political courses in universities, middle schools and primary schools as an important project, adhere to the combination of problem-oriented and goal-oriented, adhere to the integration of integrity and innovation, and promote the connotative development of ideological and political courses.

General Secretary Xi Jinping pointed out that it is necessary to coordinate the promotion of the integrated construction of ideological and political courses in universities, middle schools and primary schools as an important project, adhere to the combination of problem-oriented and goal-oriented, adhere to the integration of integrity and innovation, and promote the connotative development of ideological and political courses. To coordinate the promotion of the integrated construction of ideological and political courses in universities, middle schools and primary schools, it is necessary to focus on making a fuss about the "takeover area" between each school section and each course. The law of student growth and the law of ideological and political education are the basic principles of the integrated construction of ideological and political courses. Human growth and development are the unity of stages and continuity. This basic law of the growth and development of students determines that the development of ideological and political education must also be a phased and continuous unity.

These two unifications are the basic principles for coordinating and promoting the integrated construction of ideological and political courses in universities, middle schools and primary schools. The growth and development of students has a phased nature, which is the basic law for in-depth discussion and formation of a general consensus for many pedagogy, psychology and even philosophy research. Piaget's theory of cognitive development, Kohlberg's theory of moral development, Vygotsky's "recent development zone", Whitehead's "Rhythm of Life", etc., have all proposed or confirmed this from different disciplines. This is also the basic basis for dividing students' learning and development into elementary, middle, and university stages. The education and teaching of different 
stages must be based on the physical and psychological development level of students at different stages, and follow the requirements of the stage characteristics of the development and development of students' intelligence, emotion, and physical ability. Education beyond the "recent development zone" is inefficient, ineffective or even "ineffective" education. At the same time, the development of students is composed of "recent development zones" one after another. Each development zone is not broken, fragmented, or divided, but a continuous process. As far as ideological and political education is concerned, the development and maturity of a person's thoughts and values are not only staged, but at the same time, the continuous development of ideological concepts is formed by the connection of several stages, which ultimately manifests as the formation of a relatively stable internal consistency. . Any rupture, fragmentation, or split in education will inevitably affect the development and maturity of ideas. Therefore, to look at the teaching of ideological and political courses from the perspective of "two unifications", it is necessary to grasp the stage characteristics of students' growth and development, so as to follow the boundary of education and teaching based on the stage characteristics of the requirements and restrictions, and neither can "rush away". Nor can it be "lagging behind"; at the same time, it is necessary to jump out of the stage boundary limitation and look at the growth and development of students from a developmental, continuous, connected, and overall perspective. Only in this way can it meet the requirements of the law of student growth that is unified in stages and continuity. --Feng Xiujun, Dean of the School of Marxism, Central University of Finance and Economics

The adolescent stage is the "joint and booting stage" of life, and it is the most in need of careful guidance and cultivation. Ideological and political education must run through the entire process from children to youth. At the same time, we emphasize that ideological and political education is not only limited to the political classroom but also emphasizes that it is implemented in every class of every teacher and combined with the subjects taught to convey ideological and political education to students.

We must admit that the ideological and political integration of universities, middle schools and primary schools has achieved gratifying results in the 40 years of development. In practice, this has been manifested in the continuous improvement of awareness, gradually embodying the concept of integration in operation, and getting closer to point Integration goals. But there are still the following problems:

First of all, there is no platform and mechanism for the integrated construction of curriculum content. This is reflected in the layout of the syllabus, curriculum standards, teaching objectives, and teaching content of universities, middle schools and primary schools, and the overall arrangement has not yet been formed. Secondly, the content of ideological and political courses is duplicated. Third, there are gaps in the content of ideological and political courses. Finally, the content of ideological and political courses is inverted. Although the content of the ideological and political course as a whole embodies the line of understanding from low to high, from concrete to abstract, the phenomenon of abstract in primary schools and normative and concrete in universities still exists to varying degrees. 


\section{The Necessity and Importance of Implementing Curriculum Ideology and Politics in Middle}

\section{School English Teaching}

(1) English education integrates ideological and political

In order to meet the requirements of the new reform, high school English textbooks have also made appropriate adjustments and revisions. Many teaching contents in the new textbooks reflect the ideological and political education of students. Therefore, teachers should also change the traditional teaching methods accordingly. To be able to teach students the basic knowledge of English at the same time, cultivate students' learning ability and improve their ideological and moral cultivation. The layout of the new textbooks is closer to the daily lives of high school students. It has strong modernity, broadens students' horizons, improves students' humanistic qualities, and enables students to form good moral qualities. For this reason, teachers should organically integrate culture, emotion, and attitude education in the process of English teaching, so that students can develop comprehensively and healthily.

(2) The necessity of Ideological and political implementation

The new curriculum standard for senior high school English clearly points out that the English curriculum should pay attention to students' emotions so that students can improve their ability of independent thinking and judgment, develop their ability to communicate and cooperate with others, and enhance their ability of cross-cultural understanding and communication in the process of English learning, As we all know, middle school students are experiencing rapid physical development, and their ideology is not mature enough to distinguish right from wrong. Therefore, in all aspects of their study and life, they have to learn from each other, They are easily influenced by all kinds of bad ideas in society, but this period is also an important period for the formation of their values. The position of Ideological and political education in the whole middle school education is obvious. As an important part of middle school education, it can't be solved by only one political course, and it is no longer a matter for the head teacher alone. It also needs to infiltrate ideological and political education in other courses. As a language course, English is very persuasive in a specific context.

(3) Analysis of the importance of Ideological and political education in English teaching With the deepening of globalization, the exchanges of economic, cultural and political between China and other countries have become increasingly close. Therefore, we should pay attention to the cultivation of talents, and middle school students must have a good reserve of English knowledge, and also have good quality and noble quality. In the context of globalization, English is an indispensable language. Ideological and political education must penetrate into the teaching process of English, which is the inevitable direction of the development of Ideological and political education in China. In recent years, the continuous innovation of English curriculum and education, the infiltration of Ideological and political education in the teaching process, can effectively improve the students' language practical ability, but also exercise their will, cultivate their sentiment; also can create a more harmonious learning atmosphere, cultivate students' good learning habits, establish their self-confidence, so as to realize the all-round development of students

(4) The implementation of ideological and political education in English 
i) English, as the main cultural course in middle school, has high credit and long class hours, which provides a time guarantee for the realization of Ideological and political education. English curriculum involves three systems: compulsory curriculum, selective compulsory curriculum and elective curriculum, which runs through the learning process of middle school. The guarantee of class hours and credits is an important advantage for English subjects to play the role of Ideological and political education.

ii) English curriculum adopts an integrated teaching method, which is guided by the theme, based on discourse. This teaching feature provides situations, materials and methods for the function of Ideological and political education. The theme context of the English curriculum includes "man and self", "man and society" and "man and nature". Among them, the theme context of "human and self" includes two theme groups: life and learning, how to behave and do things, with nine sub-themes; the theme context of "human and society" includes four theme groups: social service and interpersonal communication, literature and art and sports, history, society and culture, science and technology, with 16 sub-themes; the theme context of "human and nature" includes natural ecology There are four theme groups, environmental protection, disaster prevention and space exploration, and seven sub-themes. These theme contexts are rich in content and cover a wide range, including all aspects of human life. They not only provide the theme scope for language learning but also provide the theme context and materials for the function of Ideological and political education.

\section{The Implementation of Ideological and Political Education in Middle School English Teaching}

As a compulsory basic course for students, the English course has the characteristics of large class hours, large credit ratio, and long time span. How to follow Xi Jinping's thoughts of China's socialism with Chinese characteristics and integrate ideological and political education into English teaching, cultivate students' language understanding and expression ability. Therefore, in English teaching, we need to do the following three points:

(1) Change the teaching concept and strengthen the consciousness of ideological and political education

The traditional middle school English classroom adopts the teaching method of Teacher centered and knowledge-based teaching, with the dissemination of knowledge and mastery of knowledge as the main teaching objectives. The focus of teaching is often on how to improve students' skills of listening, speaking, reading, writing, translation and others, which is not fully aware of the importance of Integrating Ideological and political education into the teaching process.

Therefore, in order to integrate ideological and political education into English teaching, English teachers must change their teaching concepts, constantly improve their ideological and political cultivation, strengthen the sense of responsibility for ideological guidance, actively become a member of Ideological and political education, strive to be qualified ideological and political theory workers in the new era, and shoulder the responsibility of students' healthy growth guidance and guide. This requires the school to always adhere to moral education as the central link of English teaching, not only pay attention to the teaching of English knowledge and skills but also integrate ideological guidance and values into all aspects of English teaching, throughout the whole process of English teaching, to help students establish a correct value on the world, so as to cultivate students to adapt to the needs of 
social development in the new era with both ability and political integrity.

(2) Excavate teaching resources and innovate the way of ideological and political education.

In English teaching, teachers should use flexible and diverse teaching methods to integrate ideological and political education into various teaching activities. The particularity of English teaching lies not only in its language education function but also in the cultural values and ideological value system embodied by the English language. In teaching English knowledge, English teachers should not be limited to the surface structure of pronunciation, vocabulary, and grammar, but also introduce relevant cultural background knowledge on this basis to give students positive guidance. For example, for the interpretation of Martin Luther King's famous speech "I Have a Dream", teachers can guide students to describe their own dreams, interpret the Chinese dream of national rejuvenation, stimulate the youth dream with the Chinese dream, and light up the ideal lamp for students to illuminate the way forward.

(3) Follow the rules of teaching and deepen the reform of ideological and political education.

In fact, the most fundamental way for English teachers to integrate ideological and political education into English teaching in middle schools is to rely on reform in education. If we follow the old ways and lack of affinity and pertinence, we can't meet the needs and expectations of students' growth, and it is difficult to achieve practical results. Only by following the rules of ideological and political work, following the rules of English teaching, following the rules of students' growth, using good methods, improving the old methods, exploring new methods, and constantly enhancing the pertinence and attraction, can the ideological and political education promote the development of students.

The core of implementing curriculum ideology and politics in Middle School English teaching is to reform the teaching content, reconstruct the teaching objectives, strengthen the construction of teaching materials and optimize the structure of teaching materials. English listening teaching, for example, should highlight differences between Chinese and western social backgrounds. Vocabulary teaching should pay attention to the contrast between Chinese and English. Reading teaching should strengthen the guidance of positive value orientation. The teaching of translation and writing ought to strengthen the national consciousness. If this requirement can be followed, the English course will have the dual function of imparting knowledge and cultivating ability and ideological and political education.

For secondary school English teachers, the idea of curriculum ideology and politics must be seeped in teaching to get the core values of traditional culture combine with teaching content organically, which requires English teachers to make every effort to start from the knowledge points of each unit when preparing the lesson and strive to dig out the humanistic materials that correspond with the teaching content and actively cultivate the ethics and humanistic emotions of middle school students.

Nowadays, middle school students are generally self-centered and even lack understanding and care for their parents, friends and classmates. In view of this situation, in English teaching, teachers can combine the textbook with real-life and giving an example that their parents work so hard for them. 
Sometimes teachers can play the relevant video clips so that students can have a deeper understanding of their parents' hardships and can tell students to understand and care for their parents. At the same time, teachers can tell the story of mountains and rivers to the students and let them know that bosom friend is hard to find and know how to cherish friends.

In junior high school English teaching, English teachers have a great space to show the innovation and improvement of teaching methods. Many contents in English textbooks are suitable to be presented in various ways. Therefore, English teachers can permeate ideological and political education through innovative teaching methods in the teaching process. For instance, English teachers can organize English story competitions within the class, which lets all students in the class according to the specific requirements put forward by the teachers to prepare well in advance. And then, students can show in class. In the meantime, the English teacher gives scores to the students according to their performances and chooses the best students to give some material rewards. To a large extent, the function of this teaching method in ideological and political education is reflected in its ability to stimulate students' sense of participation and competition and feel the fun brought by fair competition. Besides, English teachers can organize students to carry out English drama according to a story in the English textbook. In this process, the teacher can let students form a group independently and negotiate and choose their own role to perform. The teacher should give the students more freedom to play, encourage the students to use their own imagination to adapt and interpret the story. Eventually, students can perform according to the group's collective decision.

In this process, students can not only cultivate and enhance the ability of teamwork and realize the importance of teamwork, but also play a very important role in promoting the cultivation and promotion of students' innovation consciousness and innovation ability. Students can also become more confident and cheerful during the performance.

After receiving ideological and political education, students have a new understanding of English learning, and their learning enthusiasm has been improved. Ideological and political education integrated into English teaching enables students to maintain correct values in the face of the exchange and collision of different cultures, and have national consciousness, national feelings and international vision. We will uphold China's position and foster a sense of a community with a shared future for mankind by building a new era in which people's congresses will uphold moral integrity. Good ideological and political education can provide the necessary guarantee and means for efficient and high-quality education.

To sum up, it requires the joint efforts of teachers, students and schools to better integrate ideological and political education into English teaching in middle schools. Middle school English teachers should be aware of the ideological and political education responsibility they should shoulder, and find ways to integrate ideological and political education content into English teaching more naturally, more smoothly and more efficiently, so as to comprehensively improve the effectiveness of ideological and political education in English teaching. At the same time, students should also actively cooperate with teachers to complete the teaching work, and grow into a person who knows how to help each other, knows how to respect others, and has a sense of social responsibility. 


\section{Improve the Ideological and Political Quality and Teaching Ability of Middle School English Teachers}

The report to the 18th National Congress of the CPC was put forward that we should put Education first, Moral education ahead, implement quality-oriented education and raise the level of education modernization. We will train socialist builders and successors who are well developed morally, intellectually, physically and aesthetically and deliver education that the people are satisfied with. We should further emphasize the fundamental task of educating people with moral integrity, and train builders and successors for the cause of socialism with Chinese characteristics. According to the English teaching syllabus of middle schools, the goal of English teaching is not only to enable students to acquire basic English knowledge and the ability to initially use English for communication but also to enable students to be educated in ideology, morality, patriotism and socialism. Language is the carrier of culture. Integrating ideological and political education into language teaching can help students to experience cultural differences under different social systems and times while learning language skills, so as to form a correct outlook on life and values.

Teachers should have excellent professional knowledge when teaching English. They need to have a correct value of views, good professional ethics. In teaching, it is necessary for teachers to guide students correctly, strengthen ideological and political education, teach students to distinguish right from wrong, cultivate a positive outlook on life and cultivate good quality of thinking. Careful interpretation of Chinese and western cultural differences for the student lets the student to the correct values to view the difference of culture, to cultivate students English study interest, improve the quality of English teaching, ideological and political education into English teaching can improve the level of English teaching better, students not only learn a wealth of knowledge and the different cultural differences, and in the right idea to view differences, cultivate excellent successors and builders of socialism with Chinese characteristics. Teaching is the duty-bound responsibility of every teacher. It is not only to impart rich knowledge but also to teach students correct values, outlook on life and world view. Only in this way can highly effective education be played by stimulating students' enthusiasm for learning and cultivating their strong patriotism.

Strengthening ideological and political education is more conducive to enhancing national cohesion and creativity. It has been a hundred years since the May Fourth Movement. No matter in the past or at present, young people are the most active and dynamic force in the development of our country. The prosperity of a country needs young people to play their own strength but also needs teachers to actively guide young people, so it is of great significance to strengthen the ideological and political education of young people. Chinese youth are the youth with lofty ideals and rich creativity. No matter in the period of revolution, construction or reform, they have promoted the process of China's development. In the new era, under the leadership of the Communist Party of China and under the guidance of the thought of socialism with Chinese characteristics, it is of great significance to strengthen ideological and political education to maintain confidence in the path, theory and culture and realize the great rejuvenation of the nation. 


\section{References:}

[1]. National English Curriculum Standards for general High School [S] People's Education Press.

[2]. Gao Ming. The Countermeasure of Moral Education Infiltration in English Teaching in Senior High School [J]. English for Middle School Students: Foreign Language Teaching and Research 2014 (11):52.

[3]. Li Yang. Research on Moral Infiltration in English Reading Teaching in Senior High School [J]. 20( 14 ).

[4]. He Tao. Ideological and Political Education should be Better Integrated into English Teaching. Guangming Daily 2019-05-28. 